\title{
Effect of row spacing, seeding rate and nitrogen fertilization on yield and yield components of soybean
}

\author{
Einfluss von Reihenweite, Saatstärke und Düngung auf Ertrag und \\ Ertragsstruktur von Sojabohne
}

\author{
Reinhard W. Neugschwandtner ${ }^{1 *}$, Johanna Winkler ${ }^{2}$, Maria Bernhart ${ }^{2}$, Michael A. Pucher ${ }^{1}$, Martin Klug $^{1}$, \\ Christian Werni ${ }^{3}$, Eveline Adam², Hans-Peter Kaul ${ }^{1}$
}

\footnotetext{
${ }^{1}$ University of Natural Resources and Life Sciences Vienna (BOKU), Department of Crop Sciences, Institute of Agronomy, Konrad-LorenzStraße 24, 3430 Tulln, Austria

${ }^{2}$ Saatzucht Gleisdorf GmbH, Am Tieberhof 33, 8200 Gleisdorf, Austria

${ }^{3}$ Chamber of Agriculture in Styria, Division of Agronomy, Hamerlinggasse 3, 8010 Graz, Austria

* Corresponding author: reinhard.neugschwandtner@boku.ac.at
}

Received: 1 November 2019, received in revised form: 2 December 2019, accepted: 3 December 2019

\begin{abstract}
Summary
Soybean crop management have not been studied much in Central Europe as compared with cereals. We assessed the effect of variety, row spacing, seeding rate and nitrogen $(\mathrm{N})$ fertilization on yields and yield components of soybean in a two-year experiment in Gleisdorf, Austria. The varieties Lenka, Naya and Xonia were tested in row spacings of $13 \mathrm{~cm}, 38 \mathrm{~cm}$ and $76 \mathrm{~cm}$ with 30 germinable seeds $\mathrm{m}^{-2}$. Additionally, 60 seeds $\mathrm{m}^{-2}$ were tested at $13 \mathrm{~cm}$ row spacing, and $38 \mathrm{~cm}$ row spacing was additionally established with $\mathrm{N}$ fertilization. Faster soil coverage was obtained with a high seeding rate or narrower row spacings. First pod height differed between varieties and increased with higher seeding rate. Grain yield was not affected by treatments but yield components differed. The widest row spacing resulted in a lower plant density but more pods plant ${ }^{-1}$, grains plant ${ }^{-1}$, grains pod $^{-1}$ (in one year) and a higher thousand kernel weight (TKW). The higher seeding rate resulted in a higher plant density but less pods plant ${ }^{-1}$ whereas grains pod ${ }^{-1}$ and TKW did not differ. $\mathrm{N}$ fertilization did not affect the grain yield. Correlation analysis showed a high adaptability of soybean to different seeding rates and row spacings through modulation of yield components.
\end{abstract}

Keywords: Soybean, yield components, row spacing, soil coverage, first pod height

\section{Zusammenfassung}

Die Kulturführung von Soja ist im Vergleich zu Getreide in Zentraleuropa weniger untersucht. Wir haben den Einfluss von Sorte, Reihenweite, Saatstärke und Stickstoffdüngung $(\mathrm{N})$ auf Erträge und Ertragskomponenten der Sojabohne in einem zweijährigen Versuch in Gleisdorf, Österreich, untersucht. Die Sorten Lenka, Naya und Xonia wurden bei Reihenweiten von $13 \mathrm{~cm}, 38 \mathrm{~cm}$ und 76 $\mathrm{cm}$ mit 30 keimfähigen Samen $\mathrm{m}^{-2}$ getestet. Zusätzlich wurden bei der Reihenweite von $13 \mathrm{~cm} 60$ Samen $\mathrm{m}^{-2}$ und bei jener mit $38 \mathrm{~cm}$ eine N-Düngung getestet. Eine schnellere Bodenbedeckung wurde mit einer höheren Saatstärke und engeren Reihenweiten erreicht. Die unterste Hülsenansatzhöhe unterschied sich zwischen den Sorten und stieg mit der höheren Saatstärke an. Der Kornertrag wurde durch die Behandlungen nicht beeinflusst, jedoch aber die Ertragskomponenten. Die weiteste Reihenweite führte zu einer geringeren Pflanzendichte, aber mehr Hülsen Pflanze $e^{-1}$, Körner Pflanze ${ }^{-1}$, Körner Hülse ${ }^{-1}$ (in einem Jahr) und einem höheren Tausendkorngewicht (TKG). Die höhere Saatstärke führte zu einer höheren Pflanzendichte, aber weniger Hülsen Pflanze ${ }^{-1}$, während die Körner Hülse ${ }^{-1}$ und das TKG nicht beeinflusst wurden. Die N-Düngung beeinflusste den Kornertrag nicht. Die Korrelationsanalyse zeigte eine hohe Anpassungsfähigkeit der Sojabohne an verschiedene Saatstärken und Reihenweiten mittels der Anpassung der Ertragskomponenten.

Schlagworte: Sojabohne, Ertragskomponenten, Reihenweite, Bodenbedeckung, Hülsenansatzhöhe 


\section{Introduction}

Soybean is cultivated because of its high content of oil and protein for many uses in the food and feed sector (Zeller, 1999). The protein content is especially higher in soybean than that of the other major grain legumes cultivated in Central Europe (pea, faba bean and lentil) (cf. Vollmann, 2016). Soybean meal is an important protein source in farm animal nutrition with a high digestibility and additional energy content (Florou-Paneri et al., 2014).

Production of grain legumes in the European Union occupies only about three percent of the arable land, producing only about thirty percent of protein crops consumed as animal feed in the European Union. Consequently, due to the high deficit of vegetal protein for livestock, a high share of protein feedstuffs has to be imported, especially soybean meal and soybeans (Glycine $\max (\mathrm{L}$.) Merr.), mainly from Brazil, Argentina and the US (Henseler et al., 2013). These massive imports are connected with a number of environmental problems, including the destruction of natural habitats over wide areas, for example, in Brazil where soybean production is expanded on both land converted from pasture and tropical forest (Fearnside, 2001).

Taking into account production and transportation, locally produced and supplied food is recognized as more environmentally friendly, for example, due to the reduction of greenhouse gas emissions compared to imported food, and could therefore help to reduce greenhouse gas emissions and energy input (Blanke, 2008; Michalský and Hooda, 2015). Similarly, the use of regionally produced proteinrich feedstuffs for dairy production in Austria was found to result in lower greenhouse gas emissions than feeding dairy cattle with soybean meal imported from South America, predominantly due to high emission resulting from land use changes (Hörtenhuber et al., 2011). Additionally, there is an increasing interest of consumers in locally grown food for reasons such as taste and concerns regarding food safety or genetically modified food (Halweil, 2002).

All those reasons call for the reinforcement of home grown grain legumes in Central Europe. As the yields of commonly used grain legumes in Central Europe, which are mainly spring crops, are more variable than the non-legume yields in Europe (Cernay et al., 2015), new approaches have to be followed for increasing the grain legume production, especially under the conditions of climate change with higher year-round temperatures and a lower amount of total annual precipitation with a shift of the rainfall pattern to more rainfall in winter and early spring but less in summer (Trnka et al., 2011). Such approaches include winter grain legumes (Neugschwandtner et al., 2015b; 2015c), heat-tolerant new grain legumes such as chickpea (Neugschwandtner et al., 2013; 2014) and the reinforcement of the cultivation of soybean. In a large mega-environment study for Europe, Kurasch et al. (2017) have shown that the adaptive plasticity of soybean might enable its cultivation throughout Europe even at high-latitude locations in northern Europe, concluding that thereby soybean might become an integral part of a sustainable agriculture in Europe.

Soybean is a relatively young crop in the Austrian and European agriculture. First experiments with soybean in Europe were started in Austria in 1875 (Haberlandt, 1878). Further experiments have been conducted since the 1970s for grain use in Austria (Gretzmacher, 1978; Liebhard, 1980) and for fodder use in Germany (Schuster and Jobehdar-Honarnejad, 1977). In the Austrian national crop survey, soybean was first recorded in 1990. In that year, 9,271 ha soybean were cultivated in Austria, whereas 64,467 ha have been cultivated in 2017 (Statistik Austria, 2018). In 2017, Austria was ranking as number 8 among the soybean producing countries in Europe. Compared to the neighboring countries, the cultivation in 2017 was lower in Austria as compared with Italy (322,417 ha), but higher as compared to Slovakia (43,900 ha), Germany (19,000 ha), Czech Republic (15,344 ha), Hungary (7,727 ha) and Switzerland (1,695 ha) (FAOSTAT, 2017). In Austria, a nationwide survey of long-term (2003-2016) grain yield data showed that soybean had the smallest yield gap between conventional and organic production systems among major arable crops with an average relative crop yields of $93.4 \%$ in organic compared to the conventional production (mean: $2.57 \mathrm{t} \mathrm{ha}^{-1}$ ) (Brückler et al., 2017).

Row spacing and seeding rate has been of high interest in soybean research, especially in the United States in the last decades. For example, the row spacing in Iowa was in the $1960 \mathrm{~s}$ and $1970 \mathrm{~s} \geq 76 \mathrm{~cm}$ (with a traditional $102 \mathrm{~cm}$ row spacing according to Taylor, 1980), but a trend towards row spacings $<76 \mathrm{~cm}$ occurred since the 1990s (cf. De Bruin and Pedersen, 2008). Minimizing plant population but still achieving optimal yields has become an important topic due to high seed costs of soybean (Board and Kahlon, 2013).

Narrow row spacing generally were reported to increase yield. In a multi-year data survey over three geographic regions in the United States, using data from 4879 soybean fields, narrow $(38 \mathrm{~cm})$ rows had overall higher yields than wide $(76 \mathrm{~cm})$ rows. In two regions, the differences were 
larger with shorter vegetation period, whereas in the third region, the differences were low likely as environmental conditions favored canopy closure irrespective of row spacing (Andrade et al., 2019).

Diverging results have been reported for seeding rate: Cox and Cherney (2011) observed similar yields with three seeding rates in the northeastern United States and therefore recommended lower seeding rates. Contrary to this, increases in plant density caused higher yields in Austria (Gretzmacher, 1978) and eastern Germany (Stock et al., 1996). Comparing different seeding rates on three locations in Iowa, maximum grain yield was attained with the highest plant population, but the yield increase was not so high; thus, the yield benefit with the highest seeding rates was overcompensated by increased production costs (De Bruin and Pedersen, 2008). Also, in northern Nigeria, higher fodder and grain yields have been observed with higher than currently recommended seeding rates (Kamara et al., 2014). Reasons given for better yields with narrow rows and higher plant densities are the enhanced early crop growth and the higher leaf area index and light interception (Shibles and Weber, 1966; Envi, 1973; Willcott et al., 1984; Bullock et al., 1998). Further, a decrease of weed infestation and weed biomass production has been shown by both planting in narrower rows (Orlowski et al., 2012) and increasing plant densities (Liebert and Ryan, 2017).

The $\mathrm{N}$ demand of soybean is partly fulfilled by biological nitrogen fixation (BNF). In a meta-analysis on BNF of soybean, Salvagiotti et al. (2008) reported for unfertilized soybeans that $58 \%$ of total $\mathrm{N}$ uptake derived from BNF (with 46 and $74 \%$ at the $25-75 \%$ percentiles and a maximum of $98 \%$ ). $\mathrm{N}$ fixation contributed to $40-52 \%$ of overall $\mathrm{N}$ uptake in organically grown soybean in Central Europe (Schweiger et al., 2012). The further demand derives from soil mineral $\mathrm{N}$ uptake and eventually from $\mathrm{N}$ fertilizer. The effect of fertilization with manure and mineral fertilizer on soybean grown in Iran was shown to be heavily influenced by the weather conditions of the experimental years (Gretzmacher et al., 1994).

Knowledge of soil coverage, yield and yield formation of soybean as affected by row spacing, seeding rate and nitrogen fertilization under Pannonian climate conditions is limited. All yield components of soybean can be more or less influenced by various agronomic measures (Stock et al., 1996). Therefore, grain yield and formation of yield components as affected by the mentioned parameters were assessed to find the appropriate cultivation techniques for enhancing the grain yield of soybean.

\section{Material and Methods}

\subsection{Experimental site and weather conditions}

The experiment was carried out in 2016 and 2017 in Gleisdorf ( $47^{\circ} 06^{\prime} 55.1^{\prime \prime} \mathrm{N} 15^{\circ} 42^{\prime} 24.2^{\prime \prime E}, 370 \mathrm{~m}$ above sea level) in Styria (Austria) on the fields of the plant breeding company Saatzucht Gleisdorf GmbH. The experiment was conducted on a deep Cambisol with a sandy loam soil texture. The nutrient content classes were according to the Austrian guidelines for an appropriate fertilization very high for $\mathrm{P}_{2} \mathrm{O}_{5}$ and high for $\mathrm{K}_{2} \mathrm{O}$ and $\mathrm{MgO}$ in 2016, and sufficient for $\mathrm{P}_{2} \mathrm{O}_{5}$ and $\mathrm{MgO}$ and high for $\mathrm{K}_{2} \mathrm{O}$ in 2017 . The soil nitrate $\left(\mathrm{NO}_{3}-\right.$ $\mathrm{N})$ at seeding in the soil layer of $0-0.9 \mathrm{~m}$ was at $26.2 \mathrm{~g} \mathrm{~m}^{-2}$ in 2016 and at $21.3 \mathrm{~g} \mathrm{~m}^{-2}$ in 2017.

The mean annual temperature was $8.8^{\circ} \mathrm{C}$, the mean annual precipitation was $815 \mathrm{~mm}$ (1981-2010). Table 1 shows the long-term average monthly temperature and precipitation from April until September and the deviations during the growing seasons in 2016 and 2017. Both growing seasons were by a mean difference of $1.1^{\circ} \mathrm{C}$ (2016) or $1.0^{\circ} \mathrm{C}(2017)$ warmer and by a total of $-43 \mathrm{~mm}$ (2016) or $-29 \mathrm{~mm}$ (2017) dryer than the long-term average.

\subsection{Experimental treatments and design}

A combination of the two factors' variety combined with different seeding and fertilization treatments was assessed. Following three varieties were used (breeding company and year of release in brackets): Lenka (Semences Prograin Inc., 2015), Naya (Semences Prograin Inc., 2010) and Xonia (ERSA FVG, 2014). All three varieties belong in the maturity group 00 .

Five seeding and fertilization treatments were compared, which differed in the number of established germinable seeds $\mathrm{m}^{-2}(\mathrm{~S})-30$ or 60 , in row spacing (in $\mathrm{cm}$ ) $-13,38$ or $76 \mathrm{~cm}$, and in nitrogen $(\mathrm{N})$ fertilization - no fertilization or $5.4 \mathrm{~g} \mathrm{~N} \mathrm{~m}^{-2}$. $\mathrm{N}$ fertilization was applied at flowering of soybean (on the $28^{\text {th }}$ of May 2016 or the $21^{\text {st }}$ of June 2017) with calcium ammonium nitrate (CAN, 27\% N).

The implemented variants were:

- $30 \mathrm{~S} / 13 \mathrm{~cm}$

- $60 \mathrm{~S} / 13 \mathrm{~cm}$

- $\quad 30 \mathrm{~S} / 38 \mathrm{~cm}$

- $30 \mathrm{~S} / 38 \mathrm{~cm} / \mathrm{N}$

- $30 \mathrm{~S} / 76 \mathrm{~cm}$

The experiment was carried with four replications. Individual plots had an area of $12.8 \mathrm{~m}^{2}(8 \times 1.6 \mathrm{~m})$. Seed- 
Table 1. Long-term average monthly temperature and precipitation (1981-2010) and deviations during the growing seasons in 2016 and 2017 Tabelle 1. Langjährige monatliche Durchschnittswerte für Temperatur und Niederschlage (1981-2010) und deren Abweichungen in den Vegetationsperioden 2016 und 2017

\begin{tabular}{|c|c|c|c|c|c|c|}
\hline & \multicolumn{3}{|c|}{ Temperature $\left({ }^{\circ} \mathrm{C}\right)$} & \multicolumn{3}{|c|}{ Precipitation $(\mathrm{mm})$} \\
\hline & Mean & 2016 & 2017 & Mean & 2016 & 2017 \\
\hline & $(1981-2010)$ & $( \pm)$ & $( \pm)$ & $(1981-2010)$ & $( \pm)$ & $( \pm)$ \\
\hline April & 9.1 & 1.6 & 0.2 & 54 & -14 & -1 \\
\hline May & 14.4 & 0.0 & 1.2 & 85 & 21 & -29 \\
\hline June & 17.5 & 1.4 & 2.7 & 117 & -13 & -31 \\
\hline July & 19.4 & 1.5 & 1.3 & 102 & -28 & 4 \\
\hline August & 18.6 & -0.1 & 1.4 & 122 & 42 & -16 \\
\hline September & 14.0 & 2.0 & -1.0 & 83 & -51 & 44 \\
\hline
\end{tabular}

ing was performed on the $12^{\text {th }}$ of May 2016 or the $24^{\text {th }}$ of April 2017 at a seeding depth of $3 \mathrm{~cm}$. At seeding, the granular rhizobium (Bradyrhizobium japonicum) inoculant Nodular G (Serbios, Badia Polesine, Italy) was applied to the soil at a rate $8 \mathrm{~kg} \mathrm{ha}^{-1}$. The preceding crop was in both years pumpkin. Mouldboard ploughing of fields was performed in previous autumn to a depth of $25 \mathrm{~cm}$ and seedbeds were prepared with a harrow. After seeding, weed control was performed in both years with pre-emergence herbicides S-metolachlor (1200 g a.i. ha ${ }^{-1}$, Dual Gold) and pendimethalin (682.5 g a.i. ha ${ }^{-1}$, Stomp Aqua). Further weed control was performed in two split applications with each time imazamox (20 g a.i. ha ${ }^{-1}$, Pulsar 40) and thifensulfuron methyl (3.75 $\mathrm{g}$ a.i. ha $\mathrm{a}^{-1}$, Harmony SX) on the $1^{\text {st }}$ and $8^{\text {th }}$ of June 2016 and on the $16^{\text {th }}$ and $29^{\text {th }}$ of May 2017.

\subsection{Experimental measurements}

The BBCH scale (Witzenberger et al., 1989) was used for the description of growth stages. Crop stand height was measured manually in one to two week intervals during the experiment. Percentage of soil cover of the crops was measured during the growing period by image analysis of digital color pictures according to Richardson et al. (2001), and Karcher and Richardson (2005) using SigmaScan Pro5 software. Digital photos were taken of each plot from a constant height of one meter above the ground.

Plants were harvested manually by cutting 4 running meters per plot at the soil surface at full maturity on the $26^{\text {th }}$ of September 2016 or the $25^{\text {th }}$ of September 2017. First pod height was measured as a mean of five plants per plot. Plant samples were then dried at $105^{\circ} \mathrm{C}$ for $24 \mathrm{~h}$ and divided into grains, pod walls and stems and leaves to determine the yield components. Leaf litter, which was shed before the harvest, was not collected. Conse- quently, the residue yield of soybean is under-estimated and the harvest index (HI) is over-estimated. Anyhow, Schapaugh and Wilcox (1980) have shown for soybean that the actual HI correlates highly significant with the apparent HI (which is based on the above-ground biomass of mature plants without the shed plant parts), and consequently, the actual HI should permit a valid comparison of treatments.

Yield components were counted or calculated including: plant density (plants $\mathrm{m}^{-2}$ ), pod density (pods $\mathrm{m}^{-2}$ ), grain density (grains $\mathrm{m}^{-2}$ ), thousand kernel weight (TKW), pods plant $^{-1}$, grains plant ${ }^{-1}$, grains pod $^{-1}$ as well as single plant biomass, single plant grain yield and single pod grain yield.

\subsection{Statistics}

Statistical analyses were performed using SAS version 9.2. Analysis of variance (PROC ANOVA) with subsequent multiple comparisons of means were performed. Means were separated by least significant differences (LSD), when the F-test indicated factorial effects on the significance level of $\mathrm{p}<0.05$.

\section{Results}

\subsection{Crop stand height}

Crop stand height was affected by the variety and seeding and fertilization treatments in both years. Mean maximum crop stand height (over all varieties and treatments) was observed on $30^{\text {th }}$ of July 2016 with $112.2 \mathrm{~cm}$ and on $5^{\text {th }}$ of August 2017 with $93.2 \mathrm{~cm}$. In 2016, it was highest up to mid-June for Xonia and from the end of June up to early August, highest for Lenka and lowest for Naya. From midAugust on, when all varieties and especially Lenka started 
lodging, Naya had up to harvest the highest crop stands (Figure $1 \mathrm{~A}$ ). Among seeding and fertilization treatments, differences were small up to early August, when all treatments and especially $60 \mathrm{~S} / 13 \mathrm{~cm}$ started lodging. From mid-August up to harvest, $30 \mathrm{~S} / 76$ had higher crop stands than other treatments (with $30 \mathrm{~S} / 36 \mathrm{~cm}$ showing intermediate values) (Figure $1 \mathrm{~B}$ ). In 2017, Lenka had the highest crop stand from mid-June and Naya the lowest one from end of June on up to harvest (Figure $1 \mathrm{C}$ ). Among seeding and fertilization treatments, differences were small throughout the vegetation period (Figure $1 \mathrm{D}$ ).

\subsection{Soil coverage}

Soil coverage was affected by the variety and seeding and fertilization treatments in both years. In 2016, it was among varieties from early June until late July highest for Xonia (Figure $1 \mathrm{E}$ ). Among seeding and fertilization treatments, soil coverage was highest in $60 \mathrm{~S} / 13 \mathrm{~cm}$, followed by $30 \mathrm{~S} / 13 \mathrm{~cm}$ and generally lowest in $30 \mathrm{~S} / 76 \mathrm{~cm}$. A soil coverage of $>90 \%$ could be obtained by $30 \mathrm{~S} / 76 \mathrm{~cm}$ in mid-July; when differences between all treatments diminished, all other treatments had a soil coverage of $>90 \%$ already end of June (Figure 1 F). In 2017, no differences between the varieties were observed between end of May and early June. In mid-June, the soil coverage was highest for Xonia and lowest for Naya (with Lenka showing intermediate values) (Figure $1 \mathrm{G}$ ). Among seeding and fertilization treatments, $60 \mathrm{~S} / 13 \mathrm{~cm}$ had generally the highest and $30 \mathrm{~S} / 76 \mathrm{~cm}$ the lowest soil coverage (Figure $1 \mathrm{H}$ ). In both years, $\mathrm{N}$ fertilization did not affect soil coverage of the tested treatment with $38 \mathrm{~cm}$ row spacing.

\subsection{Yields}

The mean yield values over all varieties, treatments and years were: Above-ground dry matter (AGDM) - $938 \mathrm{~g}$ $\mathrm{m}^{-2}$, grain yield $-443 \mathrm{~g} \mathrm{~m}^{-2}$, pod wall yield $-153 \mathrm{~g} \mathrm{~m}^{-2}$, yield of stems and leaves $-342 \mathrm{~g} \mathrm{~m}^{-2}$, total residue yield $495 \mathrm{~g} \mathrm{~m}^{-2}$, harvest index $-47.4 \%$.

The AGDM of Xonia was higher in 2016 than that of Lenka and Naya, with no differences between varieties in 2017. The AGDM of Lenka did not differ between the years, whereas that of Naya was higher in 2017 and that of Xonia higher in 2016 (Figure 2 A). The ADGM did not differ between treatments in 2016; in 2017 is was ranked as follows: $30 \mathrm{~S} / 13 \mathrm{~cm}$ $\geq 60 \mathrm{~S} / 13 \mathrm{~cm} \geq 30 \mathrm{~S} / 38 \mathrm{~cm} / \mathrm{N} \geq 30 \mathrm{~S} / 38 \mathrm{~cm} \geq 30 \mathrm{~S} / 76 \mathrm{~cm}$. The AGDM of $60 \mathrm{~S} / 13 \mathrm{~cm}$ was higher in 2017 and that
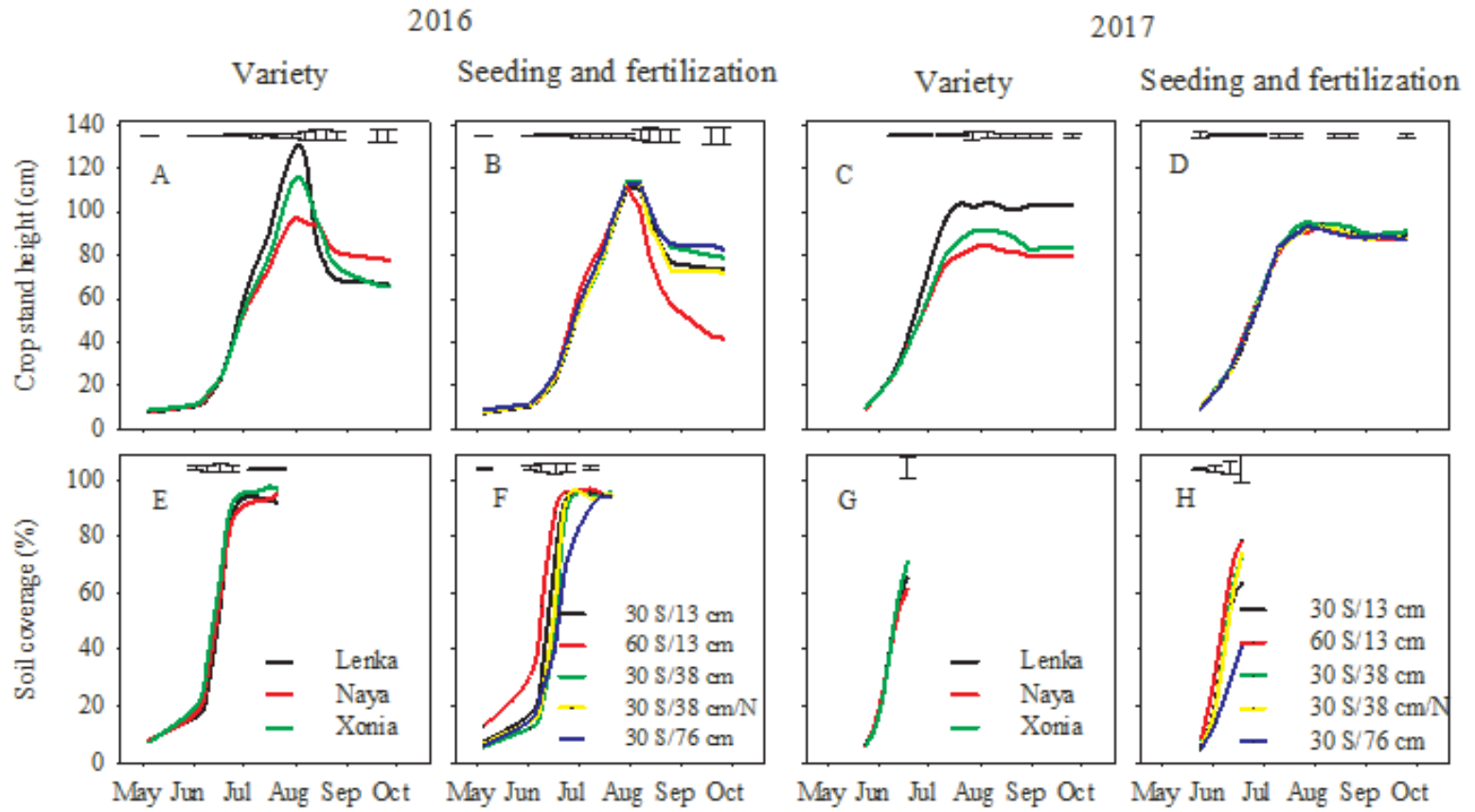

Figure 1. Crop stand height $(\mathrm{A}-\mathrm{D})$ and soil coverage $(\mathrm{E}-\mathrm{H})$ of soybean as affected by variety and seeding and fertilization treatment in 2016 and 2017. Error bars show LSDs of the factor interactions $(p<0.05)$.

Abbildung 1. Bestandeshöhe (A-D) and Bodenbedeckung (E-H) von Sojabohne in Abhängigkeit von Sorte und Aussaat- und Düngungsvariante in den Jahren 2016 und 2017. Die Fehlerbalken zeigen die Grenzdifferenz (LSD) $(\mathrm{p}<0,05)$. 


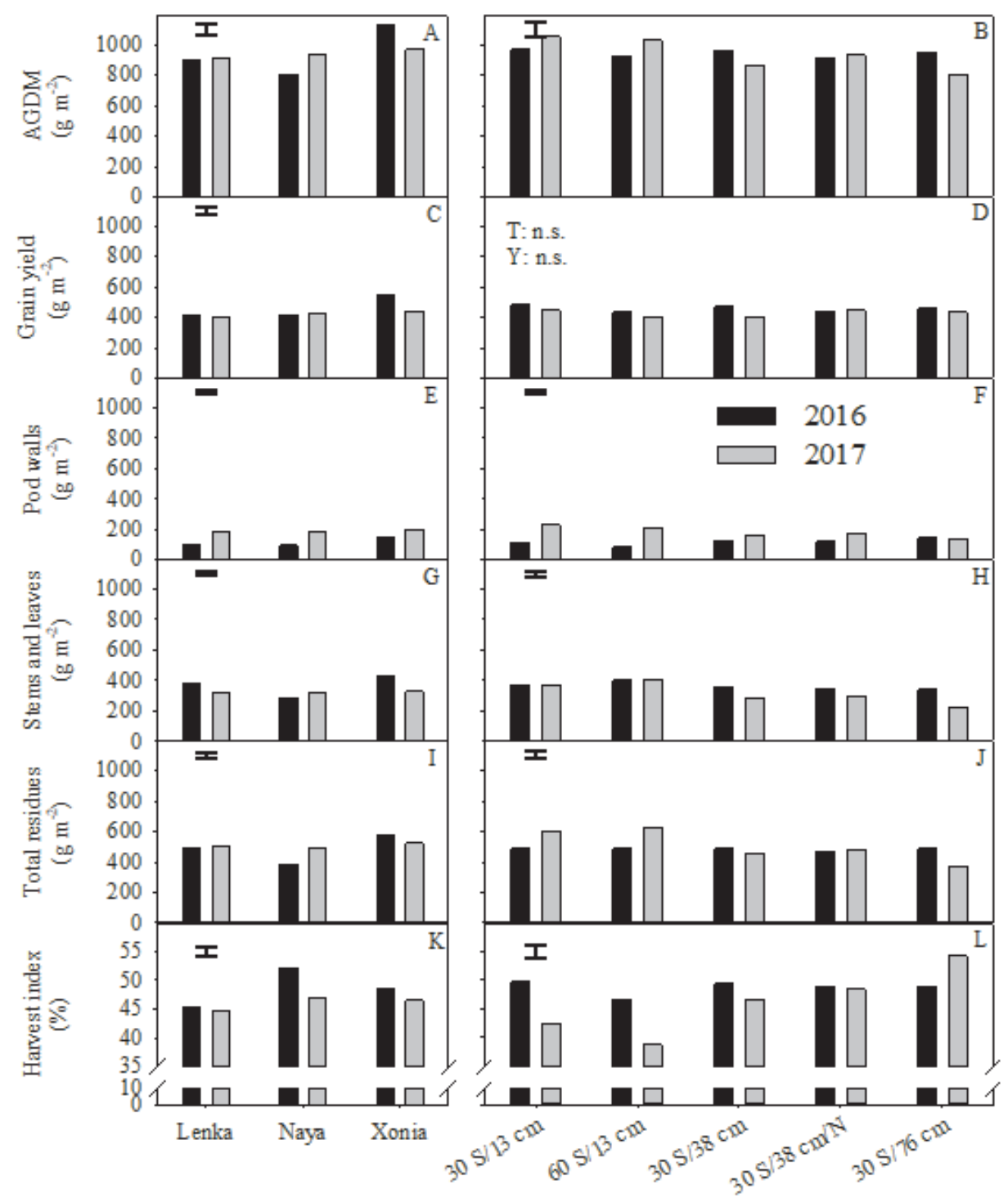

Figure 2. Yields and harvest index of soybean as affected by variety $(\mathrm{V})$ and seeding and fertilization treatment $(\mathrm{T})$ in 2016 and $2017 . \mathrm{n} . \mathrm{s} .=\mathrm{not}$ significant. Error bars show LSDs of the factor interactions $(\mathrm{p}<0.05)$.

Abbildung 2. Erträge und Ernteindex von Sojabohne in Abhängigkeit von Sorte (V) und Aussaat- und Düngungsvariante (T) in den Jahren 2016 und 2017. n. s. = nicht signifikant. Die Fehlerbalken zeigen die Grenzdifferenzen der Faktorinteraktionen $(\mathrm{p}<0,05)$.

of $30 \mathrm{~S} / 76 \mathrm{~cm}$ was higher in 2016 than in the respective other year. For other three treatments, no differences were observed between the years (Figure 2 B).

The grain yield of Xonia was higher in 2016 than that of the Lenka and Naya, with no differences between varieties in 2017 (Figure 2 C). There were no significant differences in the grain yield between the treatments and years. Grain yield was highest the for $30 \mathrm{~S} / 13 \mathrm{~cm}$ and lowest for $60 \mathrm{~S} / 13 \mathrm{~cm}$ (not significant, means over both years) (Figure $2 \mathrm{D}$ ).

The pod wall yield of Xonia was in 2016 higher than those of Lenka and Naya and in 2017 than that of Naya. The pod wall yield was higher in 2017 than in 2016 with higher differences for Lenka and Naya than for Xonia (Figure 2 E). Between seeding and fertilization treatments, it was ranked as follows: in $2016-30 \mathrm{~S} / 76 \mathrm{~cm} \geq 30 \mathrm{~S} / 38 \mathrm{~cm} \geq 30 \mathrm{~S} / 38 \mathrm{~cm} / \mathrm{N}, 30$ $\mathrm{S} / 13 \mathrm{~cm}>60 \mathrm{~S} / 13 \mathrm{~cm}$; in $2017-30 \mathrm{~S} / 13 \mathrm{~cm}, 60 \mathrm{~S} / 13 \mathrm{~cm}>$ $30 \mathrm{~S} / 38 \mathrm{~cm} / \mathrm{N}, 30 \mathrm{~S} / 38 \mathrm{~cm}>30 \mathrm{~S} / 76 \mathrm{~cm}$ (Figure $2 \mathrm{~F}$ ).

Yield of stems and leaves was in 2017 as follows: Xonia $>$ Lenka > Naya, with no differences between varieties in 2016. It was higher for Lenka and Xonia in 2016 and for Naya in 2017 compared to the other year (Figure $2 \mathrm{G}$ ). The yield of stems and leaves was for seeding and ferti- 


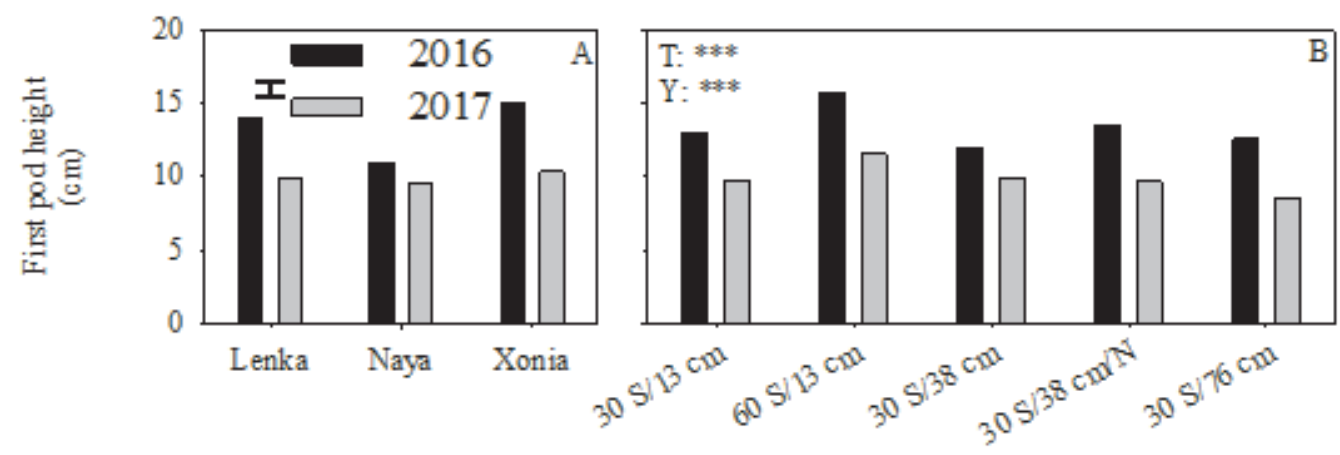

Figure 3. First pod height of soybean as affected by variety (V) and seeding and fertilization treatment (T) in 2016 and 2017 . Significant effects: $p$ $\left.<0.001{ }^{(* * *}\right)$. Error bars show LSDs of the factor interactions $(\mathrm{p}<0.05)$.

Abbildung 3. Unterste Hülsenansatzhöhe von Sojabohne in Abhängigkeit von Sorte (V) und Aussaat- und Düngungsvariante (T) in den Jahren 2016 und 2017. Signifikante Effekte: $\left.\mathrm{p}<0,001{ }^{* * *}\right)$. Die Fehlerbalken zeigen die Grenzdifferenzen (LSD) der Faktorinteraktionen $(\mathrm{p}<0,05)$.

lization treatments as follows: in $2016-60 \mathrm{~S} / 13 \mathrm{~cm} \geq$ $30 \mathrm{~S} / 13 \mathrm{~cm} \geq 30 \mathrm{~S} / 38 \mathrm{~cm}, 30 \mathrm{~S} / 38 \mathrm{~cm} / \mathrm{N}$ and $30 \mathrm{~S} / 76 \mathrm{~cm}$; in $2017-60 \mathrm{~S} / 13 \mathrm{~cm}>30 \mathrm{~S} / 13 \mathrm{~cm}>30 \mathrm{~S} / 38 \mathrm{~cm} / \mathrm{N}$, $30 \mathrm{~S} / 38 \mathrm{~cm}>30 \mathrm{~S} / 76 \mathrm{~cm}$ (Figure $2 \mathrm{H}$ ).

Total residue yield (consisting of pod walls and stems and leaves) was in 2016 as follows: Xonia > Lenka > Naya, with no differences between varieties in 2017. It was lower for Naya and higher for Xonia in 2016 than in 2017 with no differences between years for Lenka (Figure 2 I). No differences occurred for total residue yield in 2016 between treatments. Whereas in 2017, it was as follows: $60 \mathrm{~S} / 13 \mathrm{~cm}$, $30 \mathrm{~S} / 13 \mathrm{~cm}>30 \mathrm{~S} / 38 \mathrm{~cm} / \mathrm{N}, 30 \mathrm{~S} / 38 \mathrm{~cm}>30 \mathrm{~S} / 76 \mathrm{~cm}$ with higher values in 2017 for $30 \mathrm{~S} / 13 \mathrm{~cm}$ and $60 \mathrm{~S} / 13 \mathrm{~cm}$ and a lower one for $30 \mathrm{~S} / 76 \mathrm{~cm}$; total residue yields did not differ between years for $30 \mathrm{~S} / 38 \mathrm{~cm}$ and $30 \mathrm{~S} / 38 \mathrm{~cm} / \mathrm{N}$ (Figure $2 \mathrm{~J}$ ).

The harvest index (HI) was as follows: in 2016 - Naya > Xonia > Lenka; in 2017 - Naya, Xonia > Lenka. The HI of Lenka did not differ between years but those of Naya and Xonia were higher in 2016 than in 2017 (Figure $2 \mathrm{~K}$ ). For treatments, it was as follows: in $2016-30 \mathrm{~S} / 13 \mathrm{~cm}$, $30 \mathrm{~S} / 38 \mathrm{~cm} \geq 30 \mathrm{~S} / 76 \mathrm{~cm}, 30 \mathrm{~S} / 38 \mathrm{~cm} / \mathrm{N} \geq 60 \mathrm{~S} / 13 \mathrm{~cm}$; in $2017-30 \mathrm{~S} / 76 \mathrm{~cm}>30 \mathrm{~S} / 38 \mathrm{~cm} / \mathrm{N}, 30 \mathrm{~S} / 38 \mathrm{~cm}>$ $30 \mathrm{~S} / 13 \mathrm{~cm}>60 \mathrm{~S} / 13 \mathrm{~cm}$ (Figure $2 \mathrm{~L}$ ).

\subsection{First pod height}

The mean first pod height $(\mathrm{FPH})$ over all varieties, treatments and years was $11.6 \mathrm{~cm}$. There was a variety $\times$ year interaction for the FPH (Figure 3 A). The FPH of Lenka and Xonia was higher than that of Naya in 2016, but there were no differences between the varieties in 2017.
All three varieties had a higher FPH in 2016 than in 2017 with over $40 \%$ higher values for Lenka and Xonia and just 15\% higher values for Naya in 2016 than in 2017. The treatment effects on the FPH was as follows (Figure $3 \mathrm{~B}): 60 \mathrm{~S} / 13 \mathrm{~cm}>30 \mathrm{~S} / 38 \mathrm{~cm} / \mathrm{N} \geq 30 \mathrm{~S} / 13 \mathrm{~cm}$ and $30 \mathrm{~S} / 38 \mathrm{~cm} \geq 30 \mathrm{~S} / 76 \mathrm{~cm}$. The FPH of $60 \mathrm{~S} / 13 \mathrm{~cm}$ was by $3.1 \mathrm{~cm}$ or almost $30 \%$ higher than that of $30 \mathrm{~S} / 76 \mathrm{~cm}$ (13.7 cm vs. $10.6 \mathrm{~cm}$; means over both years).

\subsection{Yield components}

The mean values for yield components over all varieties, treatments and years were: plant density -33.3 plants $\mathrm{m}^{-2}$, pod density -903 pods $\mathrm{m}^{-2}$, pods plant $^{-1}-27.1$, thousand kernel weight $-224 \mathrm{~g}$, grain density -1981 grains $\mathrm{m}^{-2}$, grains plant ${ }^{-1}-64.3$, grains pod $^{-1}-2.20$.

Plant density (PID) did not differ between varieties (Figure $4 \mathrm{~A})$. Among treatments, PID was due to the higher seeding density of $60 \mathrm{~S} / 13 \mathrm{~cm}$ highest for this treatment. Among treatments sown with 30 germinable seeds $\mathrm{m}^{-2}$, PID was lowest for $30 \mathrm{~S} / 76 \mathrm{~cm}$ in 2016 and as follows in 2017: $30 \mathrm{~S} / 13 \mathrm{~cm} \geq 30 \mathrm{~S} / 38 \mathrm{~cm} / \mathrm{N} \geq 30 \mathrm{~S} / 38 \mathrm{~cm} \geq 30 \mathrm{~S} / 76 \mathrm{~cm}$. PID was significantly higher for $60 \mathrm{~S} / 13 \mathrm{~cm}$ in 2016 than in 2017 and also slightly higher for other treatments in 2016 than in 2017 (not significant) (Figure 4 B).

Pod density (PoD) was higher for Xonia than for Lenka and Naya in 2016 and did not differ between varieties in 2017. PoD of Xonia was higher in 2016 than in 2017, whereas it was not different for Lenka and Naya between years (Figure $4 \mathrm{C}$ ). The PoD was among the treatments ranked as follows: $30 \mathrm{~S} / 13 \mathrm{~cm} \geq 30 \mathrm{~S} / 38 \mathrm{~cm} / \mathrm{N} \geq 30 \mathrm{~S} / 38 \mathrm{~cm}$, $30 \mathrm{~S} / 76 \mathrm{~cm}$ and $60 \mathrm{~S} / 13 \mathrm{~cm}$ (Figure $4 \mathrm{D}$ ). 
The pods plant ${ }^{-1}$ (PoP) were more in 2017 than in 2016 and ranked among varieties as follows: Xonia > Lenka and Naya (Figure $4 \mathrm{E}$ ). Among treatments, PoP were ranked as follows: in $2016-30 \mathrm{~S} / 76 \mathrm{~cm}, 30 \mathrm{~S} / 38 \mathrm{~cm}$ $>30 \mathrm{~S} / 38 \mathrm{~cm} / \mathrm{N}, 30 \mathrm{~S} / 13 \mathrm{~cm}>60 \mathrm{~S} / 13 \mathrm{~cm}$; in 2017 $30 \mathrm{~S} / 76 \mathrm{~cm} \geq 30 \mathrm{~S} / 38 \mathrm{~cm} / \mathrm{N}, 30 \mathrm{~S} / 13 \mathrm{~cm} \geq 30 \mathrm{~S} / 38 \mathrm{~cm}$ $>60 \mathrm{~S} / 13 \mathrm{~cm}$. PoP were higher in 2017 than in 2016 for $30 \mathrm{~S} / 13 \mathrm{~cm}, 60 \mathrm{~S} / 13 \mathrm{~cm}$ and $30 \mathrm{~S} / 38 \mathrm{~cm} / \mathrm{N}$ with no differences for $30 \mathrm{~S} / 38 \mathrm{~cm}$ and $30 \mathrm{~S} / 76 \mathrm{~cm}$ (Figure $4 \mathrm{~F}$ ).

The thousand kernel weight (TKW) was ranked as follows: in 2016 - Lenka > Xonia, Naya; in 2017 -Lenka, Xonia > Naya. Lenka and Naya had a higher TKW in 2016 than in 2017 (with higher differences for Lenka than for Naya) whereas that of Xonia did not differ between years (Figure $4 \mathrm{G}$ ). Among treatments, the TKW was as follows: in $2016-60 \mathrm{~S} / 13 \mathrm{~cm}$ $\geq 30 \mathrm{~S} / 76 \mathrm{~cm}, 30 \mathrm{~S} / 38 \mathrm{~cm} \geq 30 \mathrm{~S} / 13 \mathrm{~cm} \geq 30 \mathrm{~S} / 38 \mathrm{~cm} / \mathrm{N}$; in $2017-30 \mathrm{~S} / 76 \mathrm{~cm}>30 \mathrm{~S} / 38 \mathrm{~cm} / \mathrm{N} \geq 30 \mathrm{~S} / 38 \mathrm{~cm} \geq$ $30 \mathrm{~S} / 13 \mathrm{~cm}, 60 \mathrm{~S} / 13 \mathrm{~cm}$ (Figure $4 \mathrm{H}$ ). Additionally, there was a variety $\times$ treatment interaction for the TKW: The TKW of Lenka and Naya was significantly higher with 30 S/76 cm than in the other treatments whereas for Xonia no differences between treatments were observed (data not shown).

Grain density of varieties was as follows: in 2016 - Xonia > Lenka, Naya; in 2017 - Naya $\geq$ Xonia $\geq$ Lenka. The grain density of Xonia was higher in 2016 than in 2017, with no differences between years for Lenka and Naya (Figure 4 I). Grain density did not differ between treatments with highest values for $30 \mathrm{~S} / 13 \mathrm{~cm}$ and lowest for $60 \mathrm{~S} / 13 \mathrm{~cm}$ ( $\mathrm{p}=0.14$; not significant) (Figure $4 \mathrm{~J}$ ).

Grains plant ${ }^{-1}$ were higher in 2017 than in 2016 and ranked as follows: among varieties - Xonia $>$ Naya $>$ Lenka (Figure $4 \mathrm{~K}$ ); among treatments $-30 \mathrm{~S} / 76 \mathrm{~cm}>30 \mathrm{~S} / 38 \mathrm{~cm}$ $\geq 30 \mathrm{~S} / 38 \mathrm{~cm} / \mathrm{N} \geq 30 \mathrm{~S} / 13 \mathrm{~cm}>60 \mathrm{~S} / 13 \mathrm{~cm}$ (Figure $4 \mathrm{~L}$ ). Grains pod $^{-1}$ were ranked as follows: in 2016 - Xonia, Naya > Lenka; in 2017 - Naya > Xonia > Lenka (Figure $4 \mathrm{M}$ ). Among treatments, no differences occurred in 2016, whereas treatments were ranked in 2017 as follows: $30 \mathrm{~S} / 76 \mathrm{~cm}, 30 \mathrm{~S} / 38 \mathrm{~cm} \geq 30 \mathrm{~S} / 38 \mathrm{~cm} / \mathrm{N} \geq 60 \mathrm{~S} / 13 \mathrm{~cm} \geq$ $30 \mathrm{~S} / 13 \mathrm{~cm}$ (Figure $4 \mathrm{~N}$ ).

Summarizing the effects of 30 vs. 60 seed $\mathrm{m}^{-2}$ at $13 \mathrm{~cm}$ row spacing (means over both years), the higher seeding rate resulted in a 1.64-fold higher plant density but the lower seeding rate resulted in a 1.12-fold higher grain yield due to a 1.13-fold higher pod density, whereas grains pod $^{-1}$ and TKW were not altered. On the single plant level, pods plant $^{-1}$ were 1.83 -fold and grains plant ${ }^{-1} 1.82$-fold higher with 30 compared to 60 seed $\mathrm{m}^{-2}$.

\subsection{Single plant and pod yields}

The mean values for single plant and pod yields over all varieties, treatments and years were: single plant biomass $30.2 \mathrm{~g}$, single plant grain yield $-14.4 \mathrm{~g}$, single pod grain yield $-0.49 \mathrm{~g}$.

The single plant biomass (SPB) was higher in 2017 than in 2016 and ranked among varieties as follows: Xonia > Lenka, Naya, with higher differences for Naya than for other varieties between years (Figure $5 \mathrm{~A}$ ). SPB was lower for $60 \mathrm{~S} / 13 \mathrm{~cm}$ than for the other treatments in 2017. In 2016, it was ranked as follows: $30 \mathrm{~S} / 76 \mathrm{~cm} \geq 30 \mathrm{~S} / 38 \mathrm{~cm}$ $\geq 30 \mathrm{~S} / 38 \mathrm{~cm} / \mathrm{N} \geq 30 \mathrm{~S} / 13 \mathrm{~cm}>60 \mathrm{~S} / 13 \mathrm{~cm}$ (Figure 5 B). There was a variety $x$ treatment interaction: The SPB of Lenka and Xonia was higher than that of Lenka with $30 \mathrm{~S} / 76 \mathrm{~cm}$ (data not shown).

The single plant grain yield (SPIY) was higher in 2017 than in 2016 and was ranked for varieties as follows: Xonia $>$ Naya and Lenka (Figure $5 \mathrm{C}$ ). Among the treatments, the SPIY was ranked as follows: $30 \mathrm{~S} / 76 \mathrm{~cm}>30 \mathrm{~S} / 38 \mathrm{~cm}$ $\geq 30 \mathrm{~S} / 38 \mathrm{~cm} / \mathrm{N} \geq 30 \mathrm{~S} / 13 \mathrm{~cm}>60 \mathrm{~S} / 13 \mathrm{~cm}$ (Figure $5 \mathrm{D}$ ). There was a variety $\times$ treatment interaction: The SPIY of Lenka and Xonia was higher than that of Lenka with 30 S/76 cm (data not shown).

The single pod grain yield (SPoY) was ranked for varieties as follows: Naya $\geq$ Xonia $\geq$ Lenka (Figure $5 \mathrm{E}$ ). Among treatments, the SPIY did not differ in 2016 and was ranked in 2017 as follows: $30 \mathrm{~S} / 76 \mathrm{~cm}>30 \mathrm{~S} / 38 \mathrm{~cm}, 30 \mathrm{~S} / 38 \mathrm{~cm} / \mathrm{N}$ $>60 \mathrm{~S} / 13 \mathrm{~cm}, 30 \mathrm{~S} / 13 \mathrm{~cm}$ (Figure $5 \mathrm{~F}$ ).

Summarizing the effects of 30 vs. 60 seed $\mathrm{m}^{-2}$ at $13 \mathrm{~cm}$ row spacing (means over both years), the lower seeding rate resulted in a 1.68-fold higher SPB and in a 1.81-fold higher SPIY, whereas the SPoY was the same for both seeding rates.

\subsection{Correlations among biomass fractions}

Pearson correlation coefficient for biomass fractions (all varieties, treatments and years; $n=120)$. AGDM correlated positively with grain yield $\left(\mathrm{r}=0.84^{* * *}\left[{ }^{* * *}=\mathrm{p}<0.001\right]\right)$ and biomass of pod walls $\left(\mathrm{r}=0.62^{* * *}\right)$ and stems and leaves $\left(r=0.80^{* * *}\right)$. Grain yield correlated positively with pod walls $\left(\mathrm{r}=0.34^{* * *}\right)$ and stems and leaves $\left(\mathrm{r}=0.46^{* * *}\right)$; the same for pod walls and stems and leaves $\left(\mathrm{r}=0.28^{* * *}\right)$. The HI did not correlate with AGDM $(\mathrm{r}=-0.14)$, positively with grain yield $\left(r=0.40^{* * *}\right)$ and negatively with biomass of pod walls $\left(\mathrm{r}=-0.39^{* * *}\right)$ and stems and leaves $\left(\mathrm{r}=-0.49^{* * *}\right)$. 


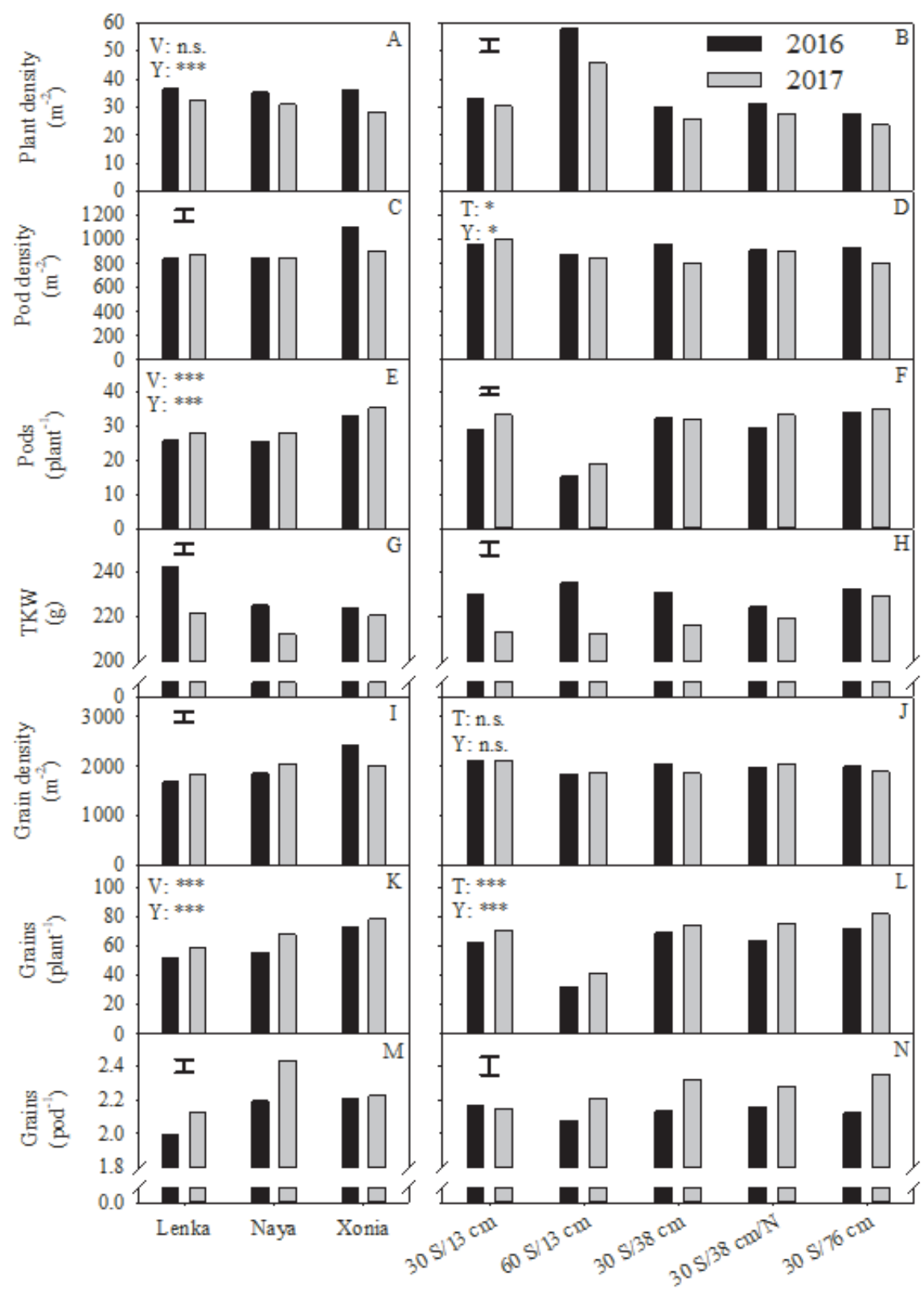

Figure 4. Yield components of soybean as affected by variety $(\mathrm{V})$ and seeding and fertilization treatment $(\mathrm{T})$ in 2016 and 2017. Significant effects: n. $s .=$ not significant, $\mathrm{p}<0.05\left(^{*}\right)$ and $\mathrm{p}<0.001\left(^{* * *}\right)$. Error bars show LSDs of the factor interactions $(\mathrm{p}<0.05)$.

Abbildung 4. Ertragskomponenten von Sojabohne in Abhängigkeit von Sorte (V) und Aussaat- und Düngungsvariante (T) in den Jahren 2016 und 2017. SignifikanteEffekte: n. $s .=$ nicht signifikant, $\mathrm{p}<0,05\left(^{*}\right)$ and $\mathrm{p}<0,001\left(^{* * *}\right)$. Die Fehlerbalken zeigen die Grenzdifferenzen (LSD) der Faktorinteraktionen $(\mathrm{p}<0,05)$.

\subsection{Correlations among biomass fractions and yield components}

For calculating the Pearson correlation coefficient of AGDM, grain yield and yield components only from treatments with 30 sown seeds were used $(n=96$; Table 2$)$.

A higher plant density increased AGDM, grain yield, pod density, grain density but pods plant ${ }^{-1}$, grains plant ${ }^{-1}$, grains pod ${ }^{-1}$, SPB, grain yield plant ${ }^{-1}$ and SPoY decreased, whereas the TKW was not affected.

Pod density correlated positively with plant density and negatively with grains pod $^{-1}$. With a higher pod density, the AGDM, grain yield, grain density, grains plant ${ }^{-1}$ and grain yield plant ${ }^{-1}$ increased but SPoY decreased, whereas the SPB was not affected. 


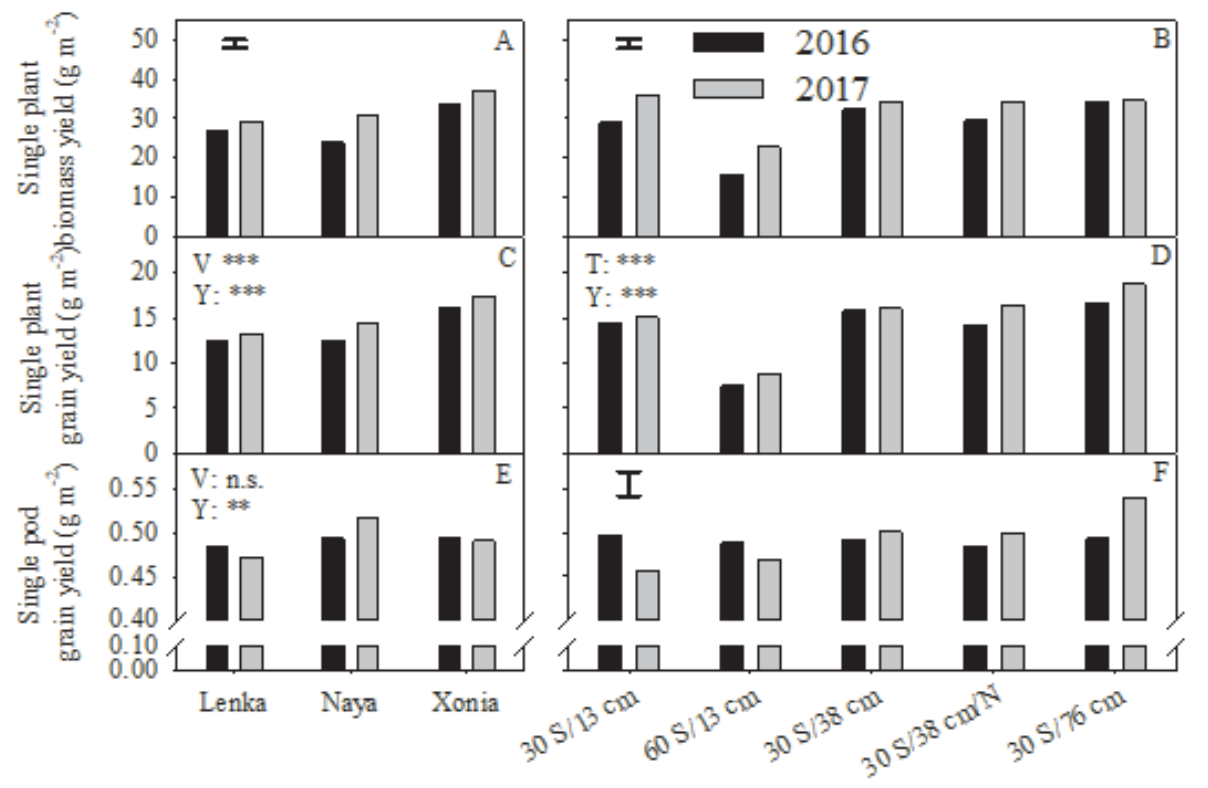

Figure 5. Single plant biomass yield, single plant grain yield and single pod grain yield of soybean as affected by variety (V) and seeding and fertilization treatment $(\mathrm{T})$ in 2016 and 2017. Significant effects: n. $s .=$ not significant, $\mathrm{p}<0.01\left({ }^{* *}\right)$ and $\mathrm{p}<0.001$ (***). Error bars show LSDs of the factor interactions $(\mathrm{p}<0.05)$.

Abbildung 5 Einzelpflanzenbiomasse, Einzelpflanzenertrag und Einzelhülsenertrag von Sojabohne in Abhängigkeit von Sorte (V) und Aussaat- und Düngungsvariante (T) in den Jahren 2016 und 2017. Signifikante Effekte: n. s. = nicht signifikant, p $<0,01(* *)$ and p $<0,001\left({ }^{* * *}\right)$. Die Fehlerbalken zeigen die Grenzdifferenzen (LSD) der Faktorinteraktionen ( $<<0,05)$.

Grains pod $^{-1}$ correlated negatively with plant density, pod density and showed no correlation with pods plant ${ }^{-1}$. An increase in grains pod $^{-1}$ resulted in a higher grain density, grains plant ${ }^{-1}$, SPB, grain yield plant ${ }^{-1}$ and SPoY, but a lower TKW whereas AGDM and grain yield were not affected. The TKW correlated negatively with grain density, grains plant $^{-1}$, grains pod $^{-1}$ but did not correlate with plant density, pod density, pods plant ${ }^{-1}$. An increase in grains pod ${ }^{-1}$ resulted in a higher SPoY, whereas AGDM, grain yield, $\mathrm{SPB}$ and grain yield plant were not affected.

\section{Discussion}

The crop stand height of Lenka was the highest in both years, but in 2016, it showed the strongest lodging among varieties resulting in higher crop stands of Naya at harvest. Also, the highest seeding rate resulted in 2016 in lodging and thus a reduced crop stand height. With widest row spacing, highest crop stand was obtained from mid-August up to harvest in 2016. De Bruin and Pedersen (2008) did not observe differences in the plant height between the row spacings of 38 and $76 \mathrm{~cm}$ of soybean tested with different seeding rates on three locations in three years in Iowa. Cox and Cherney (2011) observed a higher crop stand with $19 \mathrm{~cm}$ than with $76 \mathrm{~cm}$ but no effects of seeding rate on crop stand height.

A fast soil coverage by plants is important for radiation interception and soil protection against erosion processes (Klima et al., 2016). Among varieties, Xonia covered the soil faster than the other two. $\mathrm{N}$ fertilization did not affect soil coverage but both a higher seeding rate and narrower row spacings resulted in a faster soil coverage. In 2016, the widest row spacing attained just in mid-July, thus two weeks after the other treatments and two months after seeding, a soil coverage of $>90 \%$. Similar to the soil coverage, a higher plant density and narrower row spacing was reported to increase the leaf area index and to reduce the days to reach high solar radiation interception (Shibles and Weber, 1966). Variety effects on soil coverage have already been reported for spring barley and winter faba bean. Further, seeding date, seed size and year can affect soil coverage (Neugschwandtner et al., 2015a; 2015b; 2019a; 2019b). Grain loss during combine harvesting is a major problem in soybean cultivation. This is mainly related to the first pod high. Stock et al. (1996) have reported that high grain losses 
Table 2. Pearson correlation coefficient of AGDM, grain yield and yield components for all treatments with a seeding rate of 30 seeds $\mathrm{m}^{-2}($ all varieties, both years; $\mathrm{n}=96$ )

Tabelle 2. Korrelationskoeffizient nach Pearson für die oberirdische Biomasse, Kornertrag und die Ertragskomponenten aller Behandlungen mit der Saatstärke von 30 Körnern $\mathrm{m}^{-2}$ (alle Sorten, beide Jahre; $\mathrm{n}=96$ )

\begin{tabular}{|c|c|c|c|c|c|c|c|c|c|c|c|c|}
\hline & $\begin{array}{l}\text { Grain } \\
\text { yield }\end{array}$ & $\begin{array}{c}\text { Harvest } \\
\text { Index }\end{array}$ & $\begin{array}{c}\text { Plant } \\
\text { density }\end{array}$ & $\begin{array}{c}\text { Pod } \\
\text { density }\end{array}$ & $\begin{array}{l}\text { Pods } \\
\text { plant }^{-1}\end{array}$ & TKG & $\begin{array}{l}\text { Grain } \\
\text { density }\end{array}$ & $\begin{array}{l}\text { Grains } \\
\text { plant }^{-1}\end{array}$ & $\begin{array}{c}\text { Grains } \\
\text { pod }^{-1}\end{array}$ & SPB & SPIY & SPoY \\
\hline AGDM & $0.87^{* * *}$ & $0.87^{* * *}$ & $0.49^{* * *}$ & $0.87^{* * *}$ & $0.41^{* * *}$ & -0.09 & $0.87^{* * *}$ & $0.33^{* * *}$ & -0.02 & $0.43^{* * *}$ & $0.30^{* *}$ & -0.06 \\
\hline Grain yield & & $0.32^{* *}$ & $0.49^{* * *}$ & $0.87^{* * *}$ & $0.43^{* * *}$ & 0.04 & $0.96^{* * *}$ & $0.43^{* * *}$ & 0.17 & $0.30^{* *}$ & $0.45^{* * *}$ & $0.20^{*}$ \\
\hline Harvest Index & & & 0.01 & 0.07 & 0.11 & $0.24^{*}$ & $0.24^{*}$ & $0.27^{* *}$ & -0.01 & $0.43^{* * *}$ & $0.31^{* *}$ & -0.06 \\
\hline Plant density & & & & $0.65^{* * *}$ & $-0.43^{* * *}$ & -0.01 & $0.49^{* * *}$ & $-0.51^{* * *}$ & $-0.31^{* *}$ & $-0.56^{* * *}$ & $-0.53^{* * *}$ & $-0.31^{* *}$ \\
\hline Pod density & & & & & $0.40^{* * *}$ & -0.12 & $0.89^{* * *}$ & $0.23^{*}$ & $-0.22^{*}$ & 0.18 & $0.21^{*}$ & $-0.28^{* *}$ \\
\hline Pods plant ${ }^{-1}$ & & & & & & -0.11 & $0.44^{* * *}$ & $0.90^{* * *}$ & 0.11 & $0.87^{* * *}$ & $0.90^{* * *}$ & 0.04 \\
\hline TKG & & & & & & & $-0.23^{*}$ & $-0.21^{*}$ & $-0.28^{* *}$ & -0.09 & 0.04 & $0.31^{* *}$ \\
\hline Grain density & & & & & & & & $0.47^{* * *}$ & $0.24^{*}$ & $0.31^{* *}$ & $0.42^{* * *}$ & 0.11 \\
\hline Grains plant ${ }^{-1}$ & & & & & & & & & $0.52^{* * *}$ & $0.86^{* * *}$ & $0.97^{* * *}$ & $0.39^{* * *}$ \\
\hline Grains pod $^{-1}$ & & & & & & & & & & $0.27^{* *}$ & $0.45^{* * *}$ & $0.82^{* * *}$ \\
\hline SPB & & & & & & & & & & & $0.85^{* * *}$ & $0.21^{*}$ \\
\hline SPoY & & & & & & & & & & & & $0.47^{* * *}$ \\
\hline
\end{tabular}

AGDM = above-ground dry matter; HI = Harvest index; SPB = single plant biomass; SPlY = single plant grain yield; SPoY = single pod grain yield. Significant effects: $\mathrm{p}<0.05\left(^{(*)}, \mathrm{p}<0.01\left(^{(*}\right)\right.$ and $\mathrm{p}<0.001\left(^{(* *}\right)$.

can just be avoided if the first pod height is over $20 \mathrm{~cm}$. In our experiment, the first pod height differed between years and was higher for Lenka and Xonia than that of Naya in one year. Also, Popovic et al. (2012) reported for soybean that the first pod height differed between varieties. The first pod height was highest in the treatment with the double amount of sown seeds and lowest with the widest row spacing. Similar to our observations, a strong increase of the first pod high with higher plant densities has been shown by Stock et al. (1996). Further seeding date can influence the first pod height as shown for chickpea, where with earlier seeding, the plant height and thereby the FPH increased (López-Bellido et al., 2008).

Xonia had in 2016 a higher grain yield, pod wall yield and stems and leaves yield, and thus, the highest AGDM yield compared to the other varieties, whereas the AGDM and grain yield did not differ between the varieties in 2017. Seeding and fertilization treatments had no effect on ADGM and the grain yield in 2016 but in 2017, the ADGM was highest with narrow row spacing and decreased with increasing row spacings. Grain yield did not differ between treatments in both years. Pod wall yield was highest with wide spacing and lowest with narrow row spacing in 2016 and the other way around in 2017. Yield of stems and leaves was in both years highest with narrow row spacing and lowest with wide row spacing. Thus, no differences in total residue yield occurred in 2016 but in 2017, it was highest with narrow and lowest with wide row spacing. Consequently, the lowest HI with highest seeding rate was a result of the tendency, that with higher seeding rate, the lowest grain yield was obtained (as AGDM was in both years high with the higher seeding rate) and the highest $\mathrm{HI}$ in 2017 with wide row spacing was a result of the low AGDM yield (and no differences between grain yields).

Narrower row spacing and higher seeding rate have been reported to increase the yield due to a higher leaf area index and less days to reach high solar radiation interception (Shibles and Weber, 1966; Willcott et al., 1984) and enhanced early growth (Bullock et al., 1998). Contrary to that, we found no difference for grain yield in both years and a lower AGDM with wider row spacing just in one year. Also, contrary to our observations that no interaction of experimental factors occurred, Willcott et al. (1984) reported for the grain yield of soybean a variety $\times$ row spacing $\times$ seeding density interaction.

The harvest index was the lowest with highest seeding rate in both years and narrower row spacing in one year. With a higher plant density and narrower plant spacing, the HI was reported to decrease as full radiation interception during seed formation is required for maximum seed yield, and conditions resulting in a high seasonal interception like higher plant density may not result in highest seed yield (Shibles and Weber, 1966). Further, the crop growth rate but not the relative growth increases with higher plant densities, resulting in a higher AGDM with increasing seeding rate but lower grain yield and impaired formation of yield components (Envi, 1973). 
The grain yield of the varieties did not differ in 2017, but in 2016, the grain yield of Xonia was higher than that of the Lenka and Naya, which was a combination of the general higher plant density (of all varieties) in 2016 than in 2017 and a higher number of pods plant ${ }^{-1}$ of Xonia in both years. Although grain yield did otherwise not differ, the yield formation through yield components differed between the three varieties: Xonia had the highest number of pods plant ${ }^{-1}$ and thus also the highest PoD and due to more grains pod $^{-1}$ also the highest grain density. Lenka had the lowest number of grains pod $^{-1}$ and also the lowest number of grains plant ${ }^{-1}$ (as also pods plant ${ }^{-1}$ and the pod density were lower than that of Xonia but similar to that of Naya). Naya had in 2017 the highest number of grains pod $^{-1}$ but the lowest TKW.

Among treatments with 30 sown seeds, the widest row spacing resulted in the lowest plant density, presumably due to higher intra-row competition compared to plants sown in narrower rows. Whereas pods plant ${ }^{-1}$, TKW and grains plant ${ }^{-1}$ and grains pod $^{-1}$ (in 2017) of that treatment were the highest. Consequently, a similar grain density but a lower pod density was achieved. The single plant biomass was the highest in 2017, the SPIY in both years and single pod grain yield in 2017. Similar to Ferreira et al. (2018), who reported a higher production of pods and grains in branches with narrower row spacing, we also observed more pods plant ${ }^{-1}$ and more grains plant ${ }^{-1}$ with wider row spacings. Contrary to our observations, Cox and Cherney (2011) reported for three row spacings (19, 38 and $76 \mathrm{~cm}$ ) no differences in the plant density but a lower AGDM and grain yield with wider row spacing due to a lower pod density, a lower grain density and a lower number of grains plant $^{-1}$, whereas grains pod $^{-1}$ increased as also observed in our study with wider row spacing. Anyhow, yield components of individual plants were shown to be more affected by plant spacing within a row than by the row spacing itself (Worku and Astatkie, 2011).

A higher seeding rate at $13 \mathrm{~cm}$ row spacing resulted in a higher plant density but a lower grain yield, as the pod density was lower with the higher seeding rate. Also, the single plant biomass, the SPIY and pods plant ${ }^{-1}$ were considerably reduced, whereas seeding rate had no influence on grains pod $^{-1}$, TKW and the single pod grain yield. Cox and Cherney (2011) had already reported for four seeding rates a similar grain yield as single plant biomass and side branches plant $t^{-1}$, pods plant ${ }^{-1}$ and grains plant ${ }^{-1}$ were lower with the higher plant density, whereas grains pod $^{-1}$ and TKW were not affected by seeding rate. Contrary to that, Envi (1973) observed a decrease of the TKW of side branches with increasing seeding rate. Ferreira et al. (2018) reported that with increasing seeding rate, the number of pods plant $^{-1}$ was reduced in a greater magnitude at the branches than at the main stem whereas grain $\operatorname{pod}^{-1}$ was neither altered in the pods located at the stem or at the branches when the plant arrangement changed. Similar to these observations for soybean, also in faba bean, different plant densities tended not to affect the pod density (Patrick and Stoddard, 2010), as competition between plants generally reduced pods plant ${ }^{-1}$ rather than grains pod $^{-1}$ or seed size (Adisarwanto and Knight, 1997).

Different morphological responses (e.g., through branching) between varieties to different seeding rates have already been shown by Board and Kahlon (2013). The higher SPB and SPIY of Xonia compared to Lenka and Naya and the higher TKW of Lenka and Naya compared to Xonia with $30 \mathrm{~S} / 76 \mathrm{~cm}$ but not with other treatments indicate that there are also different morphological responses of varieties to the altered row spacing. Similar to these observations, Aufhammer and Kübler (1997) also reported for silage maize a decrease of the single plant yield but no effects on dry matter yields per area with increasing plant density.

No yield response was observed due to the application of $5.4 \mathrm{~g} \mathrm{~N} \mathrm{~m}^{-2}$ at flowering. Although with $\mathrm{N}$ fertilization, less pods plant ${ }^{-1}$ and a lower TKW was observed in 2016 as compared to the unfertilized treatment with the same row spacing; no differences occurred for pod density, grain density, grains plant ${ }^{-1}$ and grains pod $^{-1}$ in both years. Also, the single plant biomass, the single plant grain yield and the single pod grain yield were similar for both treatments in both years. Soil mineral nitrogen at seeding was in both years very high. So obviously, soybean could fulfill its $\mathrm{N}$ demand through the available soil $\mathrm{N}$ and $\mathrm{N}$ fixation, needing no further mineral N. In experiments performed in Argentina and Nebraska (USA), which had a wide range of seed yields, a yield response to $\mathrm{N}$ fertilizer was just observed in environments with a high yield potential, where indigenous $\mathrm{N}$ sources were insufficient to fully satisfy the crop N demand (Cafaro La Menza et al., 2017). Further, $\mathrm{N}$ application at flowering might not be the best time for $\mathrm{N}$ fertilization. In a synthesis-analysis comparing experiments over the United States, $\mathrm{N}$ fertilization had a measurable, but small effect on soybean yield. Across all experiments, split $\mathrm{N}$ application was more effective than a single $\mathrm{N}$ application and $\mathrm{N}$ application before the reproductive stage was more effective than $\mathrm{N}$ application during the reproductive stage (Mourtzinis et al., 2018). 
Correlation analysis showed that grain yield increased with an increase of the AGDM, harvest index and the plant and pod density. TKG and grain pod ${ }^{-1}$ did not affect the grain yield but their combined effect (SPoY) had a positive effect on it. A higher SPIY resulted from more pods plant ${ }^{-1}$ and grains pod ${ }^{-1}$ whereas TKW had no effect; and a higher SPoY resulted from more grains pod $^{-1}$ and a higher TKW. Similar to our observations, Sudarić and Vratarić (2002) reported a positive correlation of grain yield with pods plant ${ }^{-1}$, grains plant $^{-1}$, SPIY, HI but they also reported a positive correlation with TKW. They also found no correlation of pods plant ${ }^{-1}$ with TKW and HI. Also, Stock et al. (1996) reported a positive correlation of grain yield with pods plant ${ }^{-1}$ but also contrary to our results, a positive correlation of grain yield with grains pod $^{-1}$ and TKW and a negative correlation with plant density. TKW was in our experiments just positively correlated with $\mathrm{HI}$, with no other parameters affecting it. Contrary to that, Weatherspoon and Wentz (1934) have found a negative correlation of TKW and pods plant ${ }^{-1}$. Our correlation results and similarities or differences to other experiments highlight the high phenotypic plasticity of soybean to undergo changes in morphology during adaption to distinct environmental conditions (cf. Ferreira et al., 2018).

\section{Conclusion}

Crop management techniques such as choice of variety, seeding rate, row spacing and $\mathrm{N}$ fertilization might affect crop stand height and soil coverage. But grain yield of soybean remained stable over a wide range of row spacings and also between different seeding rates and with $\mathrm{N}$ fertilization. Soybean is obviously highly adaptable to different conditions through compensation or competition processes during the formation of yield components. Consequently, from an agronomic point of view, cultivation with a low seeding rate, a wider row spacing and no $\mathrm{N}$ fertilization can be recommended.

\section{Acknowledgements}

The experiments were conducted within the EIP project Innobrotics, which was founded by the Republic of Austria, the Austrian Federal States and the European Union (Contact: ARGE Innobrotics, Hamerlinggasse 3, A-8010 Graz, christian.werni@lk-stmk.at).

\section{References}

Adisarwanto, T. and R. Knight (1997): Effect of sowing date and plant density on yield and yield components in the faba bean. Australian Journal of Agricultural Research 48, 1161-1168.

Andrade, J.F., Rattalino Edreira, J.I., Mourtzinis, S., Conley, S.P., Ciampitti, I.A., Dunphy, J.E., Gaska, J.M., Glewen, K., Holshouser, D.L., Kandel, H.J., Kyveryga, P., Lee, C.D., Licht, M.A., Lindsey, L.E., McClure, M.A., Naeve, S., Nafziger, E.D., Orlowski, J.M., Ross, J., Staton, M.J., Thompson, L., Specht, J.E. and P. Grassini (2019): Assessing the influence of row spacing on soybean yield using experimental and producer survey data. Field Crops Research 230, 98-106.

Aufhammer, W. and E. Kübler (1997): Einfluss von Reihenweite und Untersaat auf den Silomaisertrag und den $\mathrm{N}_{\text {min }}$-Gehalt im Boden nach der Ernte. Die Bodenkultur 48, 151-158.

Blanke, M.M. (2008): Life cycle assessment (LCA) and food miles - An energy balance for fruit imports versus home-grown apples. Acta Horticulturae 767, 59-64.

Board, J.E. and C.S. Kahlon (2013): Morphological responses to low plant population differ between soybean genotypes. Crop Science 53, 1109-1119.

Brückler, M., Resl, T. and A. Reindl (2017): Comparison of organic and conventional crop yields in Austria. Die Bodenkultur: Journal of Land Management, Food and Environment 68, 223-236.

Bullock, D., Khan, S. and A. Rayburn (1998): Soybean yield response to narrow rows is largely due to enhanced early growth. Crop Science 38, 1011-1016.

Cafaro La Menza, N., Monzon, J.P., Specht, J.E. and P. Grassini (2017): Is soybean yield limited by nitrogen supply? Field Crops Research 213, 204-212.

Cernay, C., Ben-Ari, T., Pelzer, E., Meynard, J.-M. and D. Makowski (2015): Estimating variability in grain legume yields across Europe and the Americas. Scientific Reports 5, 11171.

Cox, W.J. and J.J. Cherney (2011): Growth and yield responses of soybean to row spacing and seeding rate. Agronomy Journal 103, 123-128.

De Bruin, J.L. and P. Pedersen (2008): Effect of row spacing and seeding rate on soybean yield. Agronomy Journal 100, 704-710.

Enyi, B.A.C. (1973): Effect of plant population on growth and yield of soya bean (Glycine max). The Journal of Agricultural Science 81, 131-138. 
FAOSTAT (2017): http://www.fao.org/faostat/en/\#data/ QC. Accessed on 19 March 2019.

Fearnside, P.M. (2001): Soybean cultivation as a threat to the environment in Brazil. Environmental Conservation 28, 23-38.

Ferreira, A.S., Zucareli, C., Werner, F. and A.A. Balbinot Junior (2018): Plant spatial arrangement affects grain production from branches and stem of soybean cultivars. Bragantia 77, 567-576.

Florou-Paneri, P., Christaki, E., Giannenas, I., Bonos, E., Skoufos, I., Tsinas, A., Tzora, A. and J. Peng (2014): Alternative protein sources to soybean meal in pig diets. Journal of Food, Agriculture and Environment 12, 655-660.

Gretzmacher, R. (1978): Die Reaktion der Sojabohne (Glycine max (L.) Merr.) auf unterschiedliche Bestandesdichten. Die Bodenkultur 29, 333-350.

Gretzmacher, R., Schahbazian, N. and N. Pourdavai (1994): Einfluß von symbiontischem, organischem und anorganischem Stickstoff auf Ertrag und Qualität von Sojabohnen. Die Bodenkultur 45, 253-267.

Haberlandt, F. (1878): Die Sojabohne. Ergebnisse der Studien und Versuche über die Anbauwürdigkeit dieser neu einzuführenden Culturpflanze. Verlag Carl Gerold's Sohn, Wien.

Halweil, B. (2002): Home grown: The case for local food in a global market. Worldwatch Paper 163, 5-79.

Henseler, M., Piot-Lepetit, I., Ferrari, E., Mellado, A.G., Banse, M., Grethe, H., Parisi, C. and S. Hélaine (2013): On the asynchronous approvals of GM crops: Potential market impacts of a trade disruption of EU soy imports. Food Policy 41, 166-176.

Henseler, M., Piot-Lepetit, I., Ferrari, E., Mellado, A.G., Banse, M., Grethe, H., Parisi, C. and S. Hélaine (2013): On the asynchronous approvals of GM crops: Potential market impacts of a trade disruption of EU soy imports. Food Policy 41, 166-176.

Hörtenhuber, S.J., Lindenthal, T. and W. Zollitsch (2011): Reduction of greenhouse gas emissions from feed supply chains by utilizing regionally produced protein sources: The case of Austrian dairy production. Journal of the Science of Food and Agriculture 91, 1118-1127.

Kamara, A.Y., Ewansiha, S.U., Boahen, S. and A.I. Tofa (2014): Agronomic response of soybean varieties to plant population in the Guinea savannas of Nigeria. Agronomy Journal 106, 1051-1059.
Karcher, D.E. and M.D. Richardson (2005): Batch analysis of digital images to evaluate turfgrass characteristics. Crop Science 45, 1536-1539.

Klima, K., Wiśniowska-Kielian, B. and A. Lepiarczyk (2016): The interdependence between the leaf area index value and soil-protecting effectiveness of selected plants. Plant, Soil and Environment 62, 151-156.

Kurasch, A.K., Hahn, V., Leiser, W.L., Vollmann, J., Schori, A., Bétrix, C.-A., Mayr, B., Winkler, J., Mechtler, K., Aper, J., Sudaric, A., Pejic, I., Sarcevic, H., Jeanson, P., Balko, C., Signor, M., Miceli, F., Strijk, P., Rietman, H., Muresanu, E., Djordjevic, V., Pospišil, A., Barion, G., Weigold, P., Streng, S., Krön, M. and T. Würschum (2017): Identification of mega-environments in Europe and effect of allelic variation at maturity E loci on adaptation of European soybean. Plant, Cell \& Environment 40, 765-778.

Liebert, J.A. and M.R. Ryan (2017): High planting rates improve weed suppression, yield, and profitability in organically-managed, no-till-planted soybean. Weed Technology 31, 536-549.

Liebhard, P. (1980): Untersuchungen über den Einfluß der Tageslänge und der Temperatur auf Wachstum und Entwicklung mehrerer Sojabohnensorten (Glycine max. (L.) Merr.) im Freiland. Die Bodenkultur 31, 277-297. López-Bellido, F.J., López-Bellido, R.J., Khalil, S.K. and L. López-Bellido (2008): Effect of sowing date on winter kabuli chickpea growth and yield under rainfed Mediterranean conditions. Agronomy Journal, 100, 957-964.

Michalský, M. and P.S. Hooda (2015): Greenhouse gas emissions of imported and locally produced fruit and vegetable commodities: A quantitative assessment. Environmental Science and Policy, 48, 32-43.

Mourtzinis, S., Kaur, G., Orlowski, J.M., Shapiro, C.A., Lee, C.D., Wortmann, C., Holshouser, D., Nafziger, E.D., Kandel, H., Niekamp, J., Ross, W.J., Lofton, J., Vonk, J., Roozeboom, K.L., Thelen, K.D., Lindsey, L.E., Staton, M., Naeve, S.L., Casteel, S.N., Wiebold, W.J. and S.P. Conley (2018): Soybean response to nitrogen application across the United States: A synthesisanalysis. Field Crops Research 215, 74-82.

Neugschwandtner, R.W., Bernhuber, A., Kammlander, S., Wagentristl, H., Klimek-Kopyra, A. and H.-P. Kaul (2019a): Agronomic potential of winter grain legumes for Central Europe: Development, soil coverage and yields. Field Crops Research 241, 107576. 
Neugschwandtner, R.W., Böhm, K., Hall, R.M. and H.-P. Kaul (2015a): Development, growth, and nitrogen use of autumn- and spring-sown facultative wheat. Acta Agriculturae Scandinavica - Section B: Soil and Plant Science 65, 6-13.

Neugschwandtner, R.W., Papst, S., Kemetter, J., Wagentristl, H., Sedlár, O. and H.-P. Kaul (2019b): Effect of seed size on soil cover, yield, yield components and nitrogen uptake of two-row malting barley. Die Bodenkultur: Journal of Land Management, Food and Environment 70, 89-98.

Neugschwandtner, R.W., Wagentristl, H. and H.-P. Kaul (2014): Nitrogen concentrations and nitrogen yields of above-ground dry matter of chickpea during crop growth compared to pea, barley and oat in Central Europe. Turkish Journal of Field Crops 19, 136-141.

Neugschwandtner, R.W., Wichmann, S., Gimplinger, D.M., Wagentristl, H. and H.-P. Kaul (2013): Chickpea performance compared to pea, barley and oat in Central Europe: Growth analysis and yield. Turkish Journal of Field Crops 18, 179-184.

Neugschwandtner, R.W., Ziegler, K.V., Kriegner, S. and H.-P. Kaul (2015b): Limited winter survival and compensation mechanisms of yield components constrain winter faba bean production in Central Europe. Acta Agriculturae Scandinavica Section B: Soil and Plant Science 65, 496-505.

Neugschwandtner, R.W., Ziegler, K.V., Kriegner, S. and H.-P. Kaul (2015c): Nitrogen yield and nitrogen fixation of winter faba beans. Acta Agriculturae Scandinavica Section B: Soil and Plant Science 65, 658-666.

Orlowski, J., Cox, W.J., Ditommaso, A. and W. Knoblauch (2012): Planting soybean with a grain drill inconsistently increases yield and profit. Agronomy Journal 104, 1065-1073.

Patrick, J.W. and F.L. Stoddard (2010): Physiology of flowering and grain filling in faba bean. Field Crops Research 115, 234-242.

Popović, V., Vidic, M., Jockovic, D., Ikanović, J., Jakśic, S. and G. Cvijanović (2012): Variability and correlations between yield components of soybean [Glycine max (L) Merr]. Genetika 44, 33-45.

Richardson, M.D., Karcher, D.E. and L.C. Purcell (2001): Quantifying turfgrass cover using digital image analysis. Crop Science 41, 1884-1888.

Salvagiotti, F., Cassman, K.G., Specht, J.E., Walters, D.T., Weiss, A. and A. Dobermann (2008): Nitrogen uptake, fixation and response to fertilizer $\mathrm{N}$ in soybeans: a review. Field Crops Research 108, 1-13.

Schapaugh, W.T. and J.R. Wilcox (1980): Relationships between harvest index and other plant characteristics in soybeans. Crop Science 20, 529-533.

Schuster, W. and R. Jobehdar-Honarnejad (1977): Untersuchungen über die Leistungsfähigkeit der Sojabohne als Grünfutterpflanze in Mitteleuropa. Die Bodenkultur 28, 245-262.

Schweiger, P., Hofer, M., Hartl, W., Wanek, W. and J. Vollmann (2012): $N_{2}$ fixation by organically grown soybean in Central Europe: Method of quantification and agronomic effects. European Journal of Agronomy 41, 11-17.

Shibles, R.M. and C.R. Weber (1966): Interception of solar radiation and dry matter production by various soybean planting patterns. Crop Science 6, 55-59.

Statistik Austria (2018): Feldfruchtproduktion 1975 bis 2018. http://www.statistik.at/web_de/statistiken/ wirtschaft/land_und_forstwirtschaft/agrarstruktur_ flaechen_ertraege/feldfruechte/034188.html Abgerufen am 22.1.2019.

Stock, H.-G., Warnstorff, K. and M. Kazmi (1996): Analyse der Ertragsstruktur von Sojabohnen (Glycine max [L.] Merr.) auf einem Standort im mitteldeutschen Trockengebiet. Die Bodenkultur 47, 23-33.

Sudarić, A. and M. Vratarić (2002): Variability and interrelationships of grain quantity and quality characteristics in soybean. Bodenkultur 53, 137-142.

Taylor, H.M. (1980): Soybean growth and yield affected by row spacing and by seasonal water supply. Agronomy Journal 72, 543-547.

Trnka, M., Eitzinger, J., Semerádová, D., Hlavinka, P., Balek, J., Dubrovský, M., Kubu, G., Štěpánek, P., Thaler, S., Možný, M. and Z. Žalud (2011): Expected changes in agroclimatic conditions in Central Europe. Climate Change 108, 261-289.

Vollmann, J. (2016): Soybean versus other food grain legumes: A critical appraisal of the United Nations International Year of Pulses 2016. Die Bodenkultur: Journal of Land Management, Food and Environment 67, 17-24.

Weatherspoon, J.H. and J.B. Wentz (1934): A statistical analyses of yield factors in soybeans. Journal of the American Society of Agronomy 26, 524-531.

Willcott, J., Herbert, S.J. and L. Zhi-Yi (1984): Leaf area display and light interception in short-season soybeans. Field Crops Research 9, 173-182. 
Witzenberger, A., Hack, H. and T. van den Boom (1989): Erläuterungen zum BBCH-Dezimal-Code für die Entwicklungsstadien des Getreides - mit Abbildungen. Gesunde Pflanzen 41, 384-388.

Worku, M. and T. Astatkie (2011): Row and plant spacing effects on yield and yield components of soya bean varieties under hot humid tropical environment of Ethiopia. Journal of Agronomy and Crop Science 197, 67-74.
Zeller, F.J. (1999): Die Sojabohne (Glycine max (L.) Merr.): Nutzung, Genetik, Biotechnologie. Die Bodenkultur 50, 191-202. 